\title{
SUBJECT ELLIPSIS IN EARLY CHILD LANGUAGE
}

\author{
Karina Bertolino ${ }^{1 \times}$ \\ ${ }^{1}$ University of Connecticut, Storrs, Connecticut, United States
}

\begin{abstract}
This paper aims to discuss whether parametric analyses can account for missing subjects in child English. I review previous parametric analyses of missing subjects and present a new learning model built upon a more recent version of the Null Subject Parameter (Holmberg, 2010a). Parametric analyses of the phenomenon have the advantage of giving a simple answer to why children omit subjects and how they reach an adult grammar: the problem is reduced to a matter of parameter missetting and resetting. However, early parametric analyses of missing subjects (Hyams, 1986, 1991) were challenged by empirical findings (Valian, 1991; Wang et al., 1992). The pattern of subject omission in child English also cannot be explained by the new parametric learning model presented in this article. I conclude that missing subjects in English are best analyzed as subject ellipsis (i.e., 'diary drop'), an option available for English-speaking adults. Keywords: Missing Subjects; Non-Null-Subject Languages; Parameters; Subject Ellipsis; 'Diary Drop'
\end{abstract}

Obtained her PhD in the Department of Linguistics at University of Connecticut. Email: karina.bertolino@ uconn.edu. ORCID: https://orcid.org/0000-0001-5089-4688. 


\section{Introduction}

In this review article, I discuss the phenomenon of missing subjects in English-speaking children, arguing that no parametric analysis can capture the pattern of subject omission in early child language. Early parametric accounts of missing subjects (Hyams, 1986, 1991) do not account for the empirical facts (Valian, 1991). Particularly, subject omission in the speech of children acquiring English is restricted to root contexts (Rizzi, 1994). Even more recent version of the Null subject parameter (Holmberg, 2010a) cannot capture the pattern of missing subjects in the child's speech. The fact that children's missing subjects are restricted to root contexts instigated proposals which analyze these elements as analogous to subject ellipsis in 'diary drop' contexts (Rizzi, 1994; Bromberg \& Wexler, 1995). The 'diary drop' analysis of early missing subjects has been contested by Haegeman and Ihsane (2001). The authors argue that missing subjects in child language is not an analogous phenomenon to subject ellipsis in spoken adult language. This is so because while 'diary drop' in adult language is characterized by omission of articles, copula and auxiliaries in root contexts, children omit articles, copula and auxiliaries in every position in the sentence.

This article is structured as follows: in section 1, I review two approaches to missing subjects that have proved problematic during the 1980s and 1990s (Hyams, 1986, 1991). In section 2, I discuss Holmberg's (2010a) null subject related parameters and I show that missing subjects produced by Englishspeaking children are not the result of the missetting of any of these parameters. In section 3, I discuss the pattern of subject ellipsis (i.e., 'diary drop') in the speech of English-speaking adults. In section 4, I present the counterarguments to the 'diary drop' analysis of children's null subjects pointed out by Haegeman and Ihsane (2001) and I discuss how they can be accounted for if we still want to maintain the 'diary drop' analysis.

\section{Early parametric approaches to missing subjects}

Within the Principle and Parameters (P\&P) framework (Chomsky, 1981), it was a logical step to envision that children could misset parameters. This hypothesis directly addressed the fact that children acquiring non-null-subject languages, such as English, French, and Danish, are reported to drop subjects during a certain stage in their development. This stage occurs roughly from 20 to 25 months (Hyams, 1986, p. 65), although the age in which this stage lasts varies from child to child, with some children producing null subjects for much longer. During this stage, non-imperative subjectless sentences alternate with sentences having overt subjects. The following examples from English are taken from Hyams (1986, pp. 65-66) quoting Bloom's (1970), Bloom et al's (1975) and Braine's (1971) corpora. There is even the presence of minimal pairs such as (1c) $\&(2 \mathrm{c}),(1 \mathrm{~d}) \&(2 \mathrm{~d})$ : 
(1) a. Throw away.

b. Want more apples.

c. Put that on.

d. Take a nap.

(2) a. Mommy throw it away.

b. I want doggie.

c. Andrew put that on.

d. Mama take a nap.

When Hyams (1986) first approached the problem of missing subjects in English, she proposed that children initially set the Null Subject Parameter to 'yes' (i.e., null subjects are allowed). In other words, in Hyams' initial proposal, all children start out speaking a language like Italian or Spanish and later they reset the parameter to 'no' (i.e., null subjects are not allowed), if the positive evidence in the languages forces the child to do so. Hyams (1986) mentions the following triggers to reset the parameter: (i) expletives, which according to Hyams occur only in non-pro-drop languages and (ii) sentences in which a referential subject pronoun appears in contexts which would be infelicitous for a null-subject language. The trigger in (ii) needs clarification: according to Hyams (1986), the Avoid Pronoun Principle dictates that subject pronouns will be avoided except when they are required for contrast and emphasis; assuming that at this point children have a pro-drop grammar, they will also expect null pronouns except for contrast and emphasis. Once the child learns that in English contrastive and emphatic pronouns are stressed, she will see any subject pronoun which is unstressed as infelicitous, according to the Avoid Pronoun Principle. The child then deduces: if unstressed pronouns are not being used for pragmatic reasons, then they should be necessary for grammatical reasons. At this point the child will conclude that the grammar of English is not an Italian-type grammar.

Hyams' (1986) proposal made a testable prediction: early null subjects in English should have the same distribution as Italian null subjects. However, this proposal was challenged by Valian's (1991) findings. Valian reports that early null subjects are generally not produced by English-speaking children in the following contexts (3), which occur in Italian, as the examples in (4) show. Null subjects are also produced in these contexts by Italian-speaking children (Guasti, 1996).

(3) a. after wh-elements.

b. in subordinate clauses.

c. after a fronted XP other than the subject

(4) a. Cosa hai detto?

Italian

What have said

'What have you said?' 
b. Gianni ha detto che verrà.

Gianni has said that will come

'Gianni has said that he will come.'

c. Ieri ho parlato a Carlo.

Yesterday have spoken to Carlo

'Yesterday I have spoken to Carlo.'

(Guasti, 2004, p. 159)

Another account of the null subject phenomenon in English-speaking children is provided by Hyams (1991). She proposes that children acquiring languages with a poor inflectional system such as English start out with a discourse-oriented grammar (i.e., radical pro-drop language), such as Chinese and Korean. As these languages allow null subjects, children acquiring non-nullsubject languages would produce null subjects at the stage they have a radical pro-drop grammar. In this proposal, children acquiring languages with a rich inflectional system have a consistent null-subject grammar, such as Italian. Hyams develops her proposal based on Jaeggli and Safir's (1989) approach to the null subject phenomenon. According to their proposal, "morphological uniformity" accounts for the possibility of null subjects:

(5) Null subjects are permitted in all and only languages with morphologically uniform inflectional paradigms.

(Jaeggli \& Safir, 1989, p. 29)

In order to have a uniform paradigm, languages should either have an inflectional paradigm which consists entirely of complex forms, as the example in Italian below illustrates (6a), or an inflectional paradigm without any complex form, as the example in Chinese (6b) illustrates. As English does not have a uniform paradigm, it is considered a mixed system, as we can see in (6c):

(6) a. 'parlare' (to talk)

$\begin{array}{lllll}\text { 1SG } & \text { parlo } & \text { 1PL } & \text { parliamo } & \text { Italian } \\ \text { 2SG } & \text { parli } & \text { 2PL } & \text { parlate } & \\ \text { 3SG } & \text { parla } & \text { 3PL } & \text { parlano } & \end{array}$

b. 'tánlùn' (to talk) Chinese

$1 \mathrm{SG}$ tánlùn $1 \mathrm{PL}$ tánlùn

2SG tánlùn 2PL tánlùn

3SG tánlùn $3 \mathrm{PL}$ tánlùn

c. 'to talk'

$\begin{array}{lllll}\text { 1SG } & \text { talk } & \text { 1PL } & \text { talk } & \text { English } \\ \text { 2SG } & \text { talk } & \text { 2PL } & \text { talk } & \\ \text { 3SG } & \text { talks } & \text { 3PL } & \text { talk } & \end{array}$


Italian and Chinese have morphologically uniform paradigms, but in different ways. While Italian has different forms for all persons, Chinese has the same form for all persons, since the language lacks verbal inflection. English, in contrast, has a mixed system: complex forms (e.g., talks) coexist with simple forms (e.g., talk). As languages like Italian and Chinese have a uniform paradigm, null subjects are licensed in these languages, but not in languages like English, with a mixed paradigm.

For Hyams (1991), in the child's English grammar, null subjects are licensed by morphological uniformity. That is to say, at the point children are producing null subjects, they have not realized that English has a nonuniform system. Once the child realizes English has a mixed system, she should stop producing null subjects.

We just saw how null subjects are licensed (i.e., what makes null subjects possible) by the child: they are licensed by morphological uniformity. The identification of null subjects (i.e., how their referential value is recovered) occurs in different ways depending on the type of language. In richly inflected languages, such as Italian or Polish, null subjects are identified by agreement (AGR), both by children and adults. As children acquiring these languages learn the inflectional system early (Slobin, 1973), it is reasonable to assume that they are able to identify the null subject by AGR. In poorly inflected languages, such as English, the null subject produced by children is identified by a topic, as for Chinese and other languages which uniformly lack inflectional morphology.

As Hyams (1991) proposes that children start out with a radical pro-drop grammar, the prediction is that children should drop any argument in the sentence (i.e., subject or object). Nevertheless, this prediction is not confirmed by the data. In the data reviewed by Hyams (1991), English-speaking children do not produce null objects. She then provides an account for why English-speaking children allow null subjects, but disallow null objects. Consider the structures below in (7a) and (7b), a modification of Huang (1984):

\section{(7) a. TOPIC [topic $_{\mathrm{i}}\left[\mathrm{pro}_{\mathrm{i}}\right.$ INFL VP]] \\ b. ${ }^{*}$ TOPIC $_{\mathrm{i}}\left[\right.$ topic $_{\mathrm{i}}[\mathrm{NP}$ INFL $[\mathrm{V}$ pro $\mathrm{i}]]$}

In the sentence in (7a), 'topic' (i.e., sentence topic) is linked to 'TOPIC' (i.e., discourse topic) which identifies subject pro. However, in (7b), the identification of object pro is not possible. According to Huang's Generalized Control Rule (1984), empty pronominal arguments are identified by the closest identifier, which for pro in object position is the subject in (7b) and not the topic. The coindexation of pro with the NP subject would violate Principle B of Binding Theory (Chomsky, 1981). In true radical pro-drop languages, variables occur in (7) instead of a null pronoun (pro), so no Principle B violation occurs between the subject and the object in (7b); instead, the null object can be identified by the topic. That is, coindexation with the topic is impossible in $(7 b)$, since the null object is a pro which requires identification by the closest identifier. Hyams (1991) proposes that in the early grammar, the child does not have variables, 
only little pro (see also Roeper et al., 1984), which cannot be identified without violation of Principle B.

According to Hyams (1991), when a child acquiring a language like English develops the agreement system, she switches to agreement-identification of the null subject instead of topic-identification, which is reserved only to radical prodrop languages. As only rich agreement systems can identify the null subject, the English-speaking child realizes that null subjects are not possible in her language.

In Wang et al. (1992), the production of null subjects and null objects is compared between English- and Chinese-speaking children. The authors employed an elicited production task. In the earlier MLU ${ }^{1}$ stage tested (MLU = 3.5), Chinese- and English-speaking children do not differ significantly in the use of null subjects, supporting Hyams' (1991) hypothesis that children start out with a radical pro-drop language. But they do differ in the production of null subjects at the latter MLU stage $(M L U=4.5)$. Furthermore, Wang et al's (1992) findings on the production of null objects are not predicted by Hyams (1991): Chinese-speaking children produce null objects along with null subjects, while English-speaking children only produce null subjects. In Hyams' (1991) analysis, children acquiring Chinese are expected to not produce null objects, just like children acquiring English. Recall that in Hyams' analysis the reason why English-speaking children are not expected to produce null objects during the null subject phase is because they did not develop variables yet, so Englishand Chinese-speaking children should both reject null objects until they have developed variables. However, Wang et al. (1992) found that even after Englishspeaking children have developed variables (indicated by the fact that they produce wh-questions), they still produce null subjects but not null objects.

We have seen that Wang et al.s (1992) data are problematic for Hyams' (1991) hypothesis that English-speaking children start out with a radical prodrop grammar. If English-speaking children have initially a radical pro-drop grammar, then we would expect no difference in the early production of null objects in Chinese and English.

Another aspect of early null subjects that is difficult to accommodate in Hyams' (1991) analysis is that they occur in both finite and non-finite clauses. ${ }^{2}$ If the child acquiring English produces null subjects in a phase in which she thinks that her language is morphologically uniform (i.e., in the way Chinese is, without morphologically marked verbs), null subjects are not expected to co-occur when there is finite morphology on the verb (e.g., third person marking). Although the rate of null subjects is higher in non-finite than in finite clauses, null subjects in finite contexts are an option for the child acquiring English and other non-nullsubject languages, as it can be seen in the table below:

Table 1: Proportion of null subjects in finite clauses

\begin{tabular}{l|l|l|l}
\hline Language & Source & \%Null Finite & \%Null Non-finite \\
\hline English & Phillips (1995) & $30 \%$ & $58 \%$ \\
\hline
\end{tabular}




\begin{tabular}{l|l|l|l}
\hline German & Behrens (1993) & $21 \%$ & $89 \%$ \\
\hline Flemish & Krämer (1993) & $25 \%$ & $89 \%$ \\
\hline Dutch & Krämer (1993) & $28 \%$ & $58 \%$ \\
\hline
\end{tabular}

Source: Adapted from Phillips (1995)

We have seen so far that empirical evidence shows that early null subjects in English have distinct properties from null subjects in radical pro-drop languages (such as Chinese) and consistent null subject languages (such as Italian), suggesting that parametric analyses of missing subjects are problematic. ${ }^{3}$

In this paper, I intend to show that missing subjects in non-null-subject languages are not amenable to a parametric account even when a more recent version of the Null Subject Parameter is adopted (Holmberg, 2010a). Holmberg (2010a) proposed three parameters ((a) D in T, (b) P in T and (c) $\varphi$-dependence) which interact with each other to explain a complex (non-)null-subject typology. In the next section, I explain each one of these parameters and why three parameters are necessary to account for the distribution of null subjects across languages.

\section{Null Subject Parameters}

There are five types of (non-)null-subject languages: non-null-subject languages, consistent null-subject languages, semi null-subject languages, partial null-subject languages and radical pro-drop languages. This is far more than implicit in the initial formulation of the Null Subject Parameter proposed by Rizzi (1982, 1986), which establishes a binary distinction between languages that have the subject of a sentence unexpressed, as in Italian, or need to express it, as in English. The distribution of null subjects across languages is more complex than that. Non-null-subject languages, such as English and French, lack definite null subjects (except in 'diary drop' contexts) and also generic null subjects (equivalent to the overt pronoun 'one' in English). ${ }^{4}$ Consistent nullsubject languages, such as Italian and European Portuguese, allow definite null subjects under fairly unrestricted circumstances, but they disallow generic null subjects. Consistent null-subject languages resort to overt strategies to express the generic reading of pronouns: Romance languages and some Slavic languages use the clitic se/si, Hausa makes use of the impersonal pronoun á (Jaggar, 2001), Moroccan Arabic and Greek use pronouns equivalent to the generic you with 2nd person singular agreement. Semi null-subject languages (e.g., Icelandic, Yiddish, Kriyol) only allow null expletives. They generally do not have null generic subjects, but Icelandic has them. ${ }^{5}$ Partial null-subject languages (e.g., Brazilian Portuguese, Finnish and Estonian) fall in between non-null-subject languages and consistent null-subject languages in that they allow definite null subjects but in more restricted circumstances than in consistent null-subject languages. Generic null subjects are possible in partial null-subject languages. Radical prodrop languages (i.e., Chinese, Korean and Thai) allow definite null subjects, null objects and generic null subjects. 
In order to account for the distribution of definite and generic null subjects in the typology described above, Holmberg (2010a) (see also Roberts 2010) formulated the parameters $D$ in $T$ and $P$ in $T$ and $\varphi$-dependent EPP. As we will see in detail below, the first two parameters are related to each other (in a "bleeding relation"), while $\varphi$-dependent EPP is an independent parameter. These parameters were formulated in the context of the Minimalist Program (MP). In the MP, parameters refer to variations in the features of functional heads across languages (Baker, 2008a, 2008b). Particularly, the parameters above concern some of the features of T. $D$ in $T$ stands for the definiteness feature in $T$. Languages with a $\mathrm{D}$-feature in $\mathrm{T}$ allow definite null subject, while those that do not have it do not allow definite null subjects. The parameter $P$ in $T$ stands for the $P$-feature in finite $T$. The $\mathrm{P}$-feature forces the pronunciation of a category in $\mathrm{T}$ and it is important to account for the presence or absence of null expletives and embedded null subjects in languages which generally do not allow definite null subjects. The P-feature is used not only by Holmberg (2010a), but also by Landau (2006) as a mechanism to account for the pronunciation of chain copies. The $\varphi$-dependent EPP parameter stands for the EPP feature of $T$ linked to the probing $u \varphi$-features. This parameter relates to the possibility of generic null subjects in a language: languages which do not have generic null subjects have a $\varphi$-dependent EPP and languages which have generic null subjects have a $\varphi$-independent EPP. In what follows, I explain these parameters in more detail and spell out their values for different (non-)null-subject language.

The $D$ in $T$ parameter states that there is a definiteness feature ( $D$-feature) which gives the definite interpretation to a null element. Consistent null-subject languages (e.g., Italian, European Portuguese, Spanish) are the ones with D in T (i.e., these languages have a positive setting for the $\mathrm{D}$ in $\mathrm{T}$ parameter), generating null subjects with definite reference in matrix clauses. Languages which lack $\mathrm{D}$ in $\mathrm{T}$ (i.e., these languages have a negative setting for the $\mathrm{D}$ in $\mathrm{T}$ parameter) do not allow null subject pronouns with definite reference: ${ }^{6}$ these include partial null-subject languages (e.g., Brazilian Portuguese, Finnish, Marathi), semi nullsubject languages (e.g., Icelandic, Yiddish and Kriyol) and non-null-subject languages (e.g., English, Danish, French).

As it is shown in the structure in (8a), consistent null subject languages formally encode a $\mathrm{D}$-feature in $\mathrm{T}$. As finite $\mathrm{T}$ has unvalued $\varphi$-features, $\mathrm{T}$ probes for a category with matching valued features. This category with matching features is the third person subject pronoun in [Spec, $v \mathrm{P}]$. This pronoun, which has the features [3SG, uCase], is called $\varphi \mathrm{P}$ pronoun. In (8b), the $\varphi$-feature values of the pronoun are copied by T (i.e., which Roberts (2010) and Holmberg (2010a) refer to as $\mathrm{T}$ incorporation). As seen in (8b), $\mathrm{T}$ also values the unvalued case feature of the subject. As the features of the goal are a subset of the features of the probe, the probe and the goal in (8b) form a chain and as such they are subject to chain reduction. When chain reduction occurs, only one chain is pronounced, usually the highest chain copy. Therefore, the subject $\varphi \mathrm{P}$ is not pronounced, as represented in (8c). This process gives rise to a definite null subject. 
(8) a. [T, D, u $\varphi, \mathrm{NOM}][v \mathrm{P}[3 \mathrm{SG}, \mathrm{uCase}] v \ldots] \rightarrow$

b. $[\mathrm{T}, \mathrm{D}, 3 \mathrm{SG}, \mathrm{NOM}]\left[v \mathrm{P}[3 \mathrm{SG}, \mathrm{NOM}] v_{\ldots} ..\right] \rightarrow$

c. $\quad[\mathrm{T}, \mathrm{D}, 3 \mathrm{SG}, \mathrm{NOM}][v \mathrm{P}[3 \mathrm{SG}, \mathrm{NOM}] v \ldots]$

Overt definite subject pronouns (in any language) have a more complex structure than null definite subject pronouns. While the second ones are $\varphi \mathrm{P}$ pronouns (with the structure [3SG, uCase]), the first ones are not. Overt definite pronouns are pronouns with the structure $\left[_{\mathrm{DP}} \mathrm{D}\left[_{\mathrm{QP}} \varphi\left[{ }_{\mathrm{NP}} \mathrm{N}\right]\right]\right]$. As they do not form a subset with T's features, they are not subject to chain reduction, being therefore pronounced.

Generic null subjects are $\varphi \mathrm{P}$ pronouns. Recall that generic null subjects appear in partial null-subject languages and Icelandic. In the derivation of generic null subjects, finite $\mathrm{T}$ has unvalued $\varphi$-features. T probes for a category with matching valued features (9a). $\mathrm{T}$ copies the $\varphi$-features values of the subject and, in return, the subject pronoun has its Case-feature valued (9b). T and the $\varphi \mathrm{P}$ pronoun will form a chain and the subject will be deleted by chain reduction (9c). However, as these languages lack D in $\mathrm{T}$, the interpretation of the subject cannot be definite, but only generic.

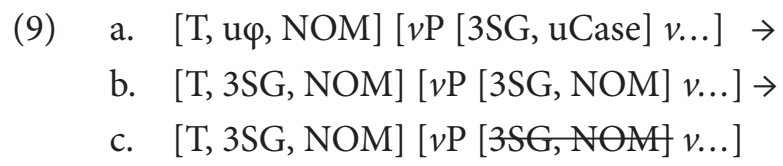

Generic overt pronouns, as in non-null-subject languages, have the structure $\left[_{q \mathrm{p}} \varphi\left[{ }_{\mathbb{N P}} \mathrm{N}\right]\right] . .^{7}$ As they have an additional NP layer, they are not incorporated to T.

As explained above, $P$ in $T$ forces the pronunciation of the subject in finite [Spec, TP]. Languages with a negative setting of this parameter allow embedded null subject in finite clauses or allow null expletives (since the pronunciation of [Spec, TP] is forced). Brazilian Portuguese (BP), for example, generally disallows third person definite null subjects in matrix clauses, since the language lacks a $\mathrm{D}$-feature in T. However, as BP has a negative setting for $\mathrm{P}$ in T (i.e., [Spec, TP] does not need to be pronounced), it allows embedded null subjects and null expletives.

Consistent null-subject languages, which have a positive setting for the $\mathrm{D}$ in $\mathrm{T}$ parameter, necessarily have a negative setting for the $\mathrm{P}$ in $\mathrm{T}$ parameter. This is so because if a language allows definite null subjects, [Spec, TP] does not need to be pronounced. Notice, however, that this is a one-way implication: languages with a negative setting for the parameter $\mathrm{D}$ in $\mathrm{T}$ do not necessarily have a positive setting for the parameter $\mathrm{P}$ in $\mathrm{T}$. English is a language with a negative setting for $\mathrm{D}$ in $\mathrm{T}$ and a positive setting for $\mathrm{P}$ in $\mathrm{T}$ (i.e., English does not allow definite null subjects and it does not allow null embedded subjects or null expletives), but BP is a language with a negative setting for $\mathrm{D}$ in $\mathrm{T}$ and a negative setting for $\mathrm{P}$ in $\mathrm{T}$.

According to Holmberg (2010a), in languages with a positive value for $\varphi$-dependent EPP, the only category that can satisfy the EPP is the goal of T's probing, that is, the DP or pronoun which values T's $\mathrm{u} \varphi$-features and is assigned 
nominative. When a language has a negative value for the parameter $\varphi$-dependent EPP, the EPP can attract other categories, such as adverbials. For example, Brazilian Portuguese (BP) has the negative setting for $\varphi$-dependent EPP. Because of the negative setting of this parameter, a fronted adverb can appear in [Spec, $\mathrm{TP}]$ in $\mathrm{BP}$, as in (10):

(10) Nessa biblioteca $\varnothing_{\text {gen }}$ não pode estudar.

In.this library not can study:INF

'In this library one cannot study.'

English is an example of language with a positive value for the $\varphi$-dependent EPP parameter, and as such, only DPs and pronouns which value T's u $\varphi$-features can appear in [Spec, TP]. All languages with generic null subjects have a negative setting for the $\varphi$-dependent EPP parameter. This is so because in sentences with generic null subjects, it is not the goal of T's probing (i.e., the generic null subject) which checks the EPP feature of T, but other categories, such an object, a locative or a temporal adverbial (see Holmberg 2005, 2010b).

The following is the hierarchical organization of these three parameters, showing the split between languages with $\mathrm{D}$ in $\mathrm{T}$ and languages without $\mathrm{D}$ in $\mathrm{T}{ }^{8}$ Table 2 gives the value of the parameters for the languages in Figure 1.

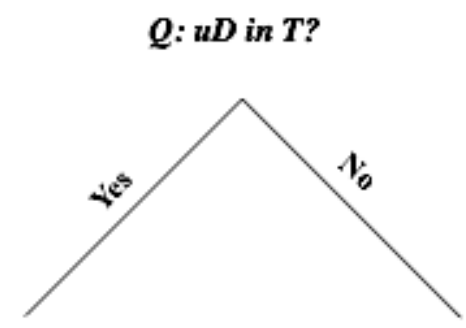

$Q: \phi$-dependent EPP?

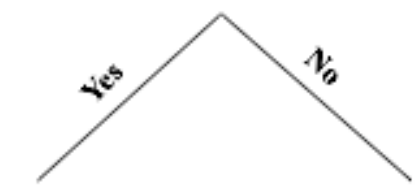

Italian,

EP
Spanish

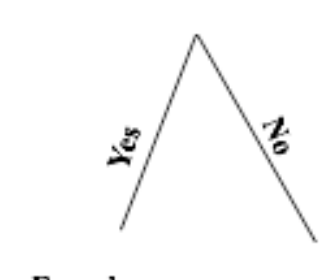

French,

English
$Q: P$ in $T$ ?

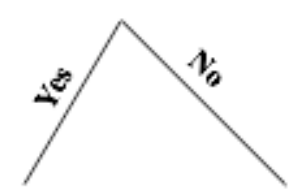

$Q: \phi$-dependent EPP?

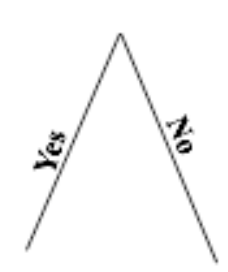

Icelandic

Kriyol
Finnish, BP 
Table 2: Null subject parameters across languages

\begin{tabular}{l|l|l|l}
\hline Language & D in T & P in T & $\varphi$-dependent \\
\hline Italian & + & - & + \\
\hline European Portuguese & + & - & + \\
\hline Spanish & + & - & - \\
\hline English & - & + & + \\
\hline French & - & + & + \\
\hline Icelandic & - & + & - \\
\hline Kriyol & - & - & + \\
\hline Finnish & - & - & - \\
\hline Brazilian Portuguese & - & - & - \\
\hline
\end{tabular}

English, the language which concerns us in this article, has a negative value for the $D$ in $T$ parameter, since the adult grammar does not allow null subjects with a definite reading (except in 'diary drop' contexts, which will be discussed in section 3). The value for the $P$ in $T$ parameter is positive in English, since [Spec, TP] cannot be empty in the language (e.g., expletives are obligatorily overt). The value for the $\varphi$-dependent parameter is also positive in English, since no other category than DPs and pronouns valuing the T's $\mathrm{u} \varphi$-features can appear in [Spec, TP].

Missing subjects cannot be analyzed as a missetting of any of Holmberg's (2010a) parameters. As a matter of fact, the initial setting of these parameters must correspond to the final setting of these parameters in non-null-subject languages, when they are deduced from the Subset Principle (Berwick, 1982; Wexler \& Manzini, 1987).

In Bertolino (2020), I deduce the initial value of the above parameters from the Subset Principle. According to this learnability principle, children select first the most restrictive value of the parameter and later, if positive evidence from the input tells the child otherwise, the parameter is reset. The most direct trigger to set the $\mathrm{D}$ in $\mathrm{T}$ parameter is the presence of third person null subjects in unrestricted environments. The initial value of the $\mathrm{D}$ in $\mathrm{T}$ parameter is negative. This is so because languages with a positive value for this parameter have definite subjects which are null or overt in matrix clauses, as shown in (12). Languages with the negative setting for this parameter only allow overt subjects in matrix clauses, as in (13). ${ }^{9}$ As $\mathrm{D}$ in $\mathrm{T}(-)$ is a subset of $\mathrm{D}$ in $\mathrm{T}(+)$, the initial value of the parameter is $\mathrm{D}$ in $\mathrm{T}(-)$.
a. Gianni va
al mare.
Italian $(\mathrm{D}$ in $\mathrm{T}(+))$
Gianni go:3SG to.the beach
'Gianni is going to the beach.'

b. Va

al mare?

Go:3SG

to.the beach

'Is (s)he going to the beach?' 
(13) a. John is going to the beach.

English (D in T (-))

b. Is ${ }^{*}(\mathrm{John})$ going to the beach?

The default value for the parameter $\mathrm{P}$ in $\mathrm{T}$ is positive, as languages with a negative setting for this parameter have [Spec, $\mathrm{TP}]$ pronounced or not as seen in (14). Languages with a negative setting of this parameter have [Spec, TP] obligatorily pronounced, as seen in (15). As $\mathrm{P}$ in $\mathrm{T}(+)$ is a subset of $\mathrm{P}$ in $\mathrm{T}(-)$, the initial value of the parameter is $\mathrm{P}$ in $\mathrm{T}(+)$.

$\mathrm{O}$ Pedro $_{\mathrm{i}}$ diz que $\left[\mathrm{TP}(\mathrm{ele})_{\mathrm{i}}\right.$ sabe inglês muito bem]. The Peter say:3SG that he know:3SG English very well 'Peter says he knows English very well.' $\quad B P(\mathrm{P}$ in $\mathrm{T}(-))$

(15) Peter says $\left[_{\mathrm{TP}}{ }^{*}(\right.$ he) knows English very well]. English (P in $\mathrm{T}(+)$ )

The default value for the $\varphi$-dependent EPP parameter is positive, as in languages with a negative setting for this parameter either the goal of T's probing can check the EPP or another element, such as an adverbial, as shown in (16). In languages with a positive setting for $\varphi$-dependent EPP parameter only the goal of T's probing which is assigned nominative case can check the EPP, as in (17).

(16) a. Nessa biblioteca $\varnothing_{\text {gen }}$ não pode estudar. $B P(\varphi$-dependent (-)) In.this library not can study:INF

In this library one cannot study.

b. O João vende livros.

The John sell:3SG books

'John sells books.'

(17) a. ${ }^{\star}$ Him gave I money.

English ( $\varphi$-dependent $(+))$

b. I gave him money.

As it can be seen in the table below, the initial value of the parameters $\mathrm{D}$ in $\mathrm{T}$, $\mathrm{P}$ in $\mathrm{T}$ and $\varphi$-dependent EPP correspond to the final values of the parameters for the non-null-subject languages such as English and French. Children acquiring these languages do not need to reset any of the Null Subject Parameters. Therefore, missing subjects cannot be the result of their missetting. Besides, these three parameters do not account for subject drop in root environments.

Table 3: Initial values of the Null Subject parameters and final values for nonnull-subject languages

\begin{tabular}{l|l|l}
\hline Parameter & Initial value & Final value \\
\hline $\mathrm{D}$ in T & - & - \\
\hline $\mathrm{P}$ in T & + & + \\
\hline D-dependent & + & + \\
\hline
\end{tabular}




\section{Subject ellipsis in adult language}

The three parameters listed in the previous section account for the distribution of null subjects in many languages. Nevertheless, there is a type of null subject which occurs in non-null-subject languages not accounted for the parameters listed above. In this section, I suggest that these null subjects result from subject ellipsis which is governed by discourse conditions.

Before discussing the proposal adopted in this article, I consider an alternative proposal which sees subject ellipsis as grammatically determined and governed by a parametric choice. According to Rizzi (1994, 2005), the 'Root subject drop' parameter governs the possibility of subject ellipsis in the specifier of the root. Rizzi (2005) argues that languages like Levantine Arabic (Kenstowicz, 1989), Franco-Provençal patois (Crousaz \& Shlonsky, 2003) and a variety of Corsican (Agostini, 1984) reflect a positive value for this parameter. According to Rizzi (2005), these languages have definite null subjects, but only in root environments. In the examples below from Levantine Arabic, the subject can be dropped in main clauses (18a), but not in embedded clauses (18b):

a. Istarat 1-fustaan.

Levantine Arabic

Bought the dress

'She bought the dress.'

b. ${ }^{*}$ Fariid kaal innu istarat 1-fustaan.

Fariid said that bought the dress

'Fariid said that she bought the dress.'

c. Fariid kaal innu ha istarat 1-fustaan.

Fariid said that she bought the dress

'Farrid said that she bought the dress.'

(Rizzi, 2005, p. 10)

In Franco-Provençal patois, the subject clitic ' $\mathrm{'}$ ' is not obligatory in the initial position of main clauses (19a). The subject is obligatory when it is non-initial (19b, c):
a. (I) travayè pra
S/he works a lot
'S/he works a lot.'
b. Portyè * (i) travayè?
Why s/he works
'Why does s/he work?'
c. Voué ${ }^{*}(\mathrm{i})$ travayè.
Today s/he works

Franco-Provençal patois 
'S/he works today'

(Rizzi, 2005, pp. 10-11)

According to Rizzi (2005), a variety of Corsican described in Agostini (1984) has a similar pattern: null subjects are optional in root contexts but disallowed when the subject is not the first element in the sentence.

Rizzi (2005, p. 15) proposes that the languages above mentioned truncate at the FinP level, licensing subject omission in the specifier of FinP, as shown in (20):

$$
\text { Force... Top... Foc... Fin.... AgrS... T... }
$$

Rizzi (2005, p. 21) suggests that truncation options are made available by UG (Universal Grammar) and therefore they result from a parametric option. He further suggests that missing subjects in English and other non-nullsubject languages result from a missetting of the 'Root Subject Drop' parameter. According to Rizzi (2005), the missetting of the 'Root Subject Drop' parameter is "performance-driven", in the sense that English-speaking children choose a positive value of this parameter to reduce computational load. This proposal, though, raises two main issues. The first one concerns the number of parameters which would be needed to explain the pattern of subject omission across languages. In the previous section, I reviewed Holmberg's (2010a) three parameters which interact with each other to explain a complex null subject typology. It is a question whether one more parameter is needed to explain subject omission in root contexts in some languages. If the advantage of formulating parameters is to facilitate the acquisition process, the greater the number of parameters, the harder the acquisition process becomes. The second issue concerns the fact that subject ellipsis in root environments is also possible in casual spoken English. If subject ellipsis in the child's language obeys the same syntactic restrictions as subject ellipsis in adult English, why would the first phenomenon result from a missetting of a parameter?

I adopt the proposal that subject ellipsis in non-null-subject languages is a discourse phenomenon, which makes unnecessary the postulation of a fourth Null Subject parameter. It is possible that under scrutiny, subject drop in Levantine Arabic, Franco-Provençal patois, and Corsican is also a discourse phenomenon.

I take "discourse phenomenon" to be the use of a linguistic construction with the purpose of conveying a specific meaning and managing the flow of the conversation. Nariyama (2004, p. 247) argues that subject ellipsis has a discourse purpose. For example, (21a) tends to imply an honest statement that the speaker actually has to leave in order to get to a certain place by a certain time. On the other hand, the statement in (21b) with subject ellipsis, implies an evasive and dismissive motive.

(21) a. I've got to go.

b. (I’ve) gotta go. 
According to Nariyama (2004), subject ellipsis is common in casual spoken English. Nariyama points out that subject ellipsis only occurs when the reference of the subject can be recovered in a previous sentence or by the context. Pragmatically, subject ellipsis is triggered when the speaker believes that the addressee can infer the identity of the null subject (Nariyama, 2004, p. 251), except in cases like (22), where the reference of the null subject is unrestricted:

\section{(I/you/we/...'ll) see what happens.}

From the syntactic viewpoint, only subjects in matrix clauses can be ellipted in finite clauses. Subject ellipsis also does not occur with auxiliary-subject inversion and in wh-questions, as shown in the examples below (Nariyama, 2004, p. 549):

(23) a. (I'll) tell you if I've got to go.

*(I'll) tell you if (I’ve) gotta go.

${ }^{\star}$ Will (you) tell me if you've got to go?

${ }^{*}$ Where're (you) going?

According to Nariyama (2004), there is a commonly held assumption that the first person pronoun is ellipted in declaratives and the second person pronoun is ellipted in interrogatives. However, the corpus study conducted by Nariyama (2004) reveals that while the majority of subject ellipses in declarative contexts occur with first person, they can also occur with other persons mainly when triggered by anaphora and conventional expressions (e.g., "don't worry about it", "could be", "not a problem"). Nariyama analyzed transcriptions of TV dramas, spoken conversations and casual letters, focusing on Australian English. The author shows that subject ellipsis is not restricted to "written registers in which pressures of economy seem to overrule the 'core' grammar" (Haegeman, 2000 , p. 132). Subject ellipsis is fairly common in spoken casual language. Besides, subject ellipsis is not driven solely by economy. Subject ellipsis in English is specifically licensed when (i) the reference of the null subject can be recovered by an anaphoric relation relying on linguistic context, (ii) in "here and now" contexts (by deixis), (iii) when the null subject is a dummy subject, and (iv) in conventional expressions (e.g., "gotta go", "see you") (Nariyama 2004). Nariyama’s data do not give us information on the frequency of subject ellipsis in adult English, as she did not calculate the percentage of subjectless sentences relative to the total number of utterances. However, by her numbers, one cannot say that subjectless sentences are rare in spoken English. Table 4 shows the number of subjectless sentences found throughout the corpora: 
Table 4: Subjectless sentences in Nariyama’s (2004) study

\begin{tabular}{l|l}
\hline Corpus & Number of subjectless sentences \\
\hline TV dramas & 53 \\
\hline Spoken conversation & 49 \\
\hline Casual letters & 20 \\
\hline
\end{tabular}

\section{Subject ellipsis in child language}

It is a question whether subject ellipsis found in adult English can be taken as analogous to early null subjects (as proposed by Bromberg and Wexler, 1995, and Rizzi, 1994). As early null subjects in children are manifested in spoken language, one can try to connect subject-drop in casual speech and early subjectdrop. The parallelism between early null subjects and adult subject ellipsis found in English and other non-null-subject languages (e.g., French) consists in the identical syntactic context in which these phenomena occur: they occur only in root environments, that is, sentence initially. However, according to Haegeman and Ihsane (2001), subject-drop in casual English has different properties than early subject-drop. These differences concern the omission of articles, auxiliaries, and copula which occurs along with subject omission:

(26) a. Articles, auxiliaries, and copula omission in adult English: confined to the initial position of the sentence.

b. Articles, auxiliaries, and copula omission in child English: can occur anywhere in the sentence.

One could argue that articles, auxiliaries, and copula omission in child English are not confined to the initial position of the sentence for independent reasons. Guasti et al. (2008) raise the hypothesis that children acquiring every language start out by assuming that their language has no article at all. The authors studied the production of articles cross-linguistically by Catalan-, Italian-, and Dutch-speaking children. They found that children go through a stage in which they omit articles, independently of their language. Romance learners soon start producing articles when they figure out that their language has a complete article paradigm. Dutchspeaking go through a second stage, taking longer to produce articles in a consistent way. This is so because in Dutch, and in other Germanic languages like English, the presence or the absence of articles varies according to the lexical item. During this second stage, Dutch-speaking children misclassify countable nouns as mass nouns (e.g., they classify 'toy', a countable noun, as a mass noun such as 'water'). Importantly, in this proposal, there is no reason for article deletion in child language to be restricted to root environments. In other words, article omission in Englishspeaking children can well be a phenomenon not related to subject omission.

Auxiliary and copula deletion has also been analyzed as a phenomenon not directly associated with missing subjects. According to Hyams (1991), children 
omit verbal morphology because they tend to make verbal paradigms uniform. As discussed in section 1, English does not have a uniform paradigm, but a mixed one, where simple forms (e.g., talk) coexist with complex forms (e.g., talks). Therefore, according to the hypothesis presented here, English-speaking children omit auxiliaries and copula because they tend to make verbal paradigm uniforms (i.e., as in languages like Chinese) and not because they omit null subjects.

Once we account for the difference concerning the pattern of omission of article, auxiliary, and copula by English-speaking children compared to adults, there is no strong argument against the 'diary drop' analysis of missing subjects in the child's speech.

As pointed out in section 1, children acquiring non-null-subject languages omit subjects in finite and non-finite clauses. The omission of subjects in finite clauses is analogous to subject ellipsis in 'diary drop'. The omission of subjects in non-finite clauses (i.e., root infinitives) can be analyzed as resulting from subject ellipsis and inflection deletion.

However, English-speaking children drop subjects more often than adults. As observed by Valian (1991), the frequency of missing subjects decreases as the child's MLU increases. This is shown in the table below. If children have the same syntax as adults, which allows subject drop in root contexts, what would explain the fact that children produce fewer null subjects over time?

Table 5: Percentage of null subjects and average MLU in English-speaking children

\begin{tabular}{l|l}
\hline Average MLU & Utterances with null subjects \\
\hline 1.77 & $73 \%$ \\
\hline 2.49 & $48 \%$ \\
\hline 3.39 & $30 \%$ \\
\hline 4.22 & $21 \%$ \\
\hline
\end{tabular}

Adapted from Valian (1991, p. 38)

Recall that, according to Nariyama (2004), subject ellipsis is triggered in pragmatic contexts in which the speaker believes that the addressee knows the identity of the null subject. I present two hypotheses to account for the gradual decreasing of null subjects in the child's speech:

(27) a. children need to learn the pragmatic/discourse conditions in which subject drop is licensed in languages like English.

b. children's high frequency of null subjects is explained by the fact that their speech is tied to the "here and now".

The hypothesis in (27a) makes the testable prediction that English-speaking children would elide subjects in pragmatic contexts in which adults do not omit 
subjects, accounting for their higher production of null subjects compared to adults. The hypothesis in (27b) states that children have no pragmatic deficit. This hypothesis predicts that the majority of null subjects produced by children occur in "here and now" contexts. This is an environment where English-speaking adults can drop subjects (Nariyama, 2004). However, it is unlikely that the adult's speech will be confined to the immediate discourse situation (e.g., adults often talk about the past and the future). Thus, children would produce more null subjects than adults because of their tendency to tie their discourse to the immediate context. Over time, as the child develops, their speech is extended to non-immediate contexts and the proportion of null subjects drops. This hypothesis, if supported, would be convergent with cross-linguistic findings. Simões (1999) studied the speech of a child acquiring BP. She found that the high frequency of null subjects used by the child compared to the adult pattern is explained by the high occurrence of "here and now" contexts in the child's speech. "Here and now" contexts also license null subjects in BP, but they are rare in the speech of adults (Simões, 1999). I leave the empirical work which could support one or both of these hypotheses for the future.

There is a potential issue with the hypotheses presented above. Nevertheless, this issue can easily be accounted for. Children acquiring consistent null-subject languages, such as Italian, omit subjects in the same proportion as adults (Valian, 1991). If English-speaking children have a pragmatic deficit (hypothesis (27a)) which would account for their high rate of subject drop, why do Italianspeaking children drop subjects at the same rate as adults? Let us take the view that Italian-speaking children have the same pragmatic deficits; however, as null subjects in Italian occur in unrestricted environments, chances are that such a pragmatic deficit would not be detected in Italian-speaking children. The same rationale can be applied for why the tendency to tie the speech to the "here and now" (hypothesis (27b)) does not cause Italian-speaking children to produce more null subjects than adults. That is to say, Italian-speaking children would have the same tendency to tie their speech to the "here and now" as English-speaking children do, however, it is likely that this would not overload the proportion of null subjects in a language in which null subjects occur in almost all instances.

\section{Concluding Remarks}

In this review paper, I discussed early parametric analyses to missing subjects in English (Hyams, 1986, 1991). These analyses proved problematic by the data presented by Valian (1991) and Wang et al. (1992). Valian (1991) observes that missing subjects in English do not occur in (i) wh-questions, (ii) embedded clauses, and (iii) after a fronted element. These findings falsified Hyams (1986) hypothesis that English-speaking children start out with an Italian-type grammar. Children acquiring Italian produce null subjects not restricted to root contexts very early on (Guasti, 1996). In other words, English missing subjects only occur 
in root contexts and the same is not true for Italian, where null subjects have a more generalized distribution.

Hyams (1991) provides a different analysis of subject omission in Englishspeaking children. She proposes that children acquiring languages with a poor inflectional system, like English, start out with a Chinese-like grammar. This is so because English-speaking children assume that the inflectional paradigm of their language is uniform, which licenses null subjects. When the child fully acquires the inflectional system of English, realizing that it is mixed and not uniform, she stops producing null subjects. In order to explain why English-speaking children do not generate null objects (which are allowed in the Chinese grammar), Hyams proposes that variables, which are responsible for licensing null objects, develop at a later point in children acquiring all languages. However, this proposal was challenged by Wang et al's findings (1992). First of all, Wang et al. (1992) found that Chinese-speaking children do produce null objects, contrarily to Hyams' prediction that both English- and Chinese-speaking children would not produce null objects. Second, Wang et al. (1992) found that the reason why Englishspeaking children do not omit objects is not related to a later development of variables: the authors found that English-speaking children produce whquestions, which require the use of variables, while they still omit subjects.

After reviewing early parametric analyses to missing subjects, I discussed a learning model built upon a more recent parametric account for null subjects (Holmberg, 2010a) in which three parameters interact with each other to explain the distribution of null subjects cross-linguistically. I concluded that the distribution of missing subjects in child English cannot be explained by a missetting of any of these parameters. In fact, the initial value of these parameters, after they are deduced from the Subset Principle, corresponds to their final values in non-null-subject languages.

I proposed that missing subjects are best analyzed as analogous to 'diary drop' in adult English. I discussed two counterarguments to the 'diary drop' analysis of missing subjects provided by Haegeman and Ihsane (2001). Namely, while articles, auxiliaries, and copula omission are confined to the sentence initial position in adult English, these elements are omitted anywhere in the sentence by English-speaking children. I showed that articles, auxiliaries, and copula omission in children can be explained by other factors: (i) cross-linguistically, it has been observed that children go through an initial phase in which they omit articles and those acquiring Germanic languages take longer to produce articles consistently (Guasti et al., 2008); (ii) auxiliaries and copula deletion can reflect a general tendency that children acquiring mixed paradigms have to delete features which belong to the verbal morphology (Hyams, 1991).

I proposed two hypotheses for why English-speaking children omit subjects at a higher rate than adults: (i) children need to learn the pragmatic/discourse conditions in which subject drop is licensed for adults; (ii) children's high frequency of null subjects is explained by the fact that their speech is tied to the "here and now". These two hypotheses shall be investigated in future work. 


\section{Acknowledgements}

Thanks to Diane-Lillo Martin whose insightful discussions, comments, and corrections on this manuscript have helped me a great deal. Thanks also to Ian Roberts for the helpful discussion on the topic. I am also grateful for the two anonymous reviewers for Ilha do Desterro, who provided very helpful comments and suggestions which led to significant revisions. All remaining errors are my own.

Notes

1. The MLU (Mean length of utterance) is the average number of morphemes per utterance produced in speech language.

2. In this article, I consider bare forms in English to be true infinitives.

3. Other approaches were proposed, such as the truncation analysis, performancebased accounts and competing grammar hypothesis. I will not discuss these proposals in this paper, although I adopt the assumption that subject drop in root contexts is an option in non-null-subject languages.

4. I restrict the discussion of generic null subjects to inclusive generic null subjects, which include the speaker and the addressee. The picture is more complex when exclusive and quasi-inclusive generic null subjects are taken into account.

5. Icelandic is sometimes classified as a partial null-subject language, since it allows generic null subjects. Other authors classify Icelandic as a semi null-subject language. This is so because differently than partial null-subject languages, Icelandic disallows embedded null subjects.

6. The discussion is restricted to third person null subject pronouns. First and second person pronouns are generated in a different way.

7. Some generic overt pronouns have the structure $\left[{ }_{N P} N\right]$.

8. Additionally to these three parameters, the hierarchical organization includes the presence or absence of $\mathrm{u} \varphi$-features in heads. Radical pro-drop languages (such as Chinese) have a negative value for $\mathrm{u} \varphi$, since they lack agreement, while all the other languages have a positive value for it.

9. English, as mentioned, allows subject drop sentence initially (i.e., when there is no element preceding the subject). However, subject ellipsis in this context is not captured by the parameter $\mathrm{D}$ in $\mathrm{T}$, as languages with a positive setting for this parameter have null subjects in unrestricted environments.

\section{References}

Agostini, P. M.(1984). L’usu di a nostra lingua: Grammaire descriptive corse: phonétique et orthographe, morphologie et syntaxe dans les parlers du Nord et du Sud de lîle. Edizioni Scola corsa Bastia.

Baker, M. (2008a). The syntax of agreement and concord. Cambridge University Press.

Baker, M. (2008b). The microparameter in a microparametric world. In T. Biberauer (Ed.), The limits of syntactic variation. (pp. 351-74). Benjamins.

Behrens, H. (1993). Temporal reference in German child language: Form and function of early verb use. Wöhrmann.

Bertolino, K. (2020). An Experimental Study on the Acquisition of Impersonal Structures in Brazilian Portuguese. [PhD dissertation]. University of Connecticut. 
Berwick, R. (1982). Locality principles and the acquisition of syntactic knowledge. Massachusetts Institute of Technology.

Bloom, L. (1970). Language development: Form and function in emerging grammars. MIT Monograph, No. 59.

Bloom, L., Lightbown, P., \& Hood, L. (1975). Structure and variation in child language. Monographs of the Society for Research in Child Development Vol. 40, No. 2, Structure and Variation in Child Language, 1-97

Braine, M. (1971). The acquisition of language in infants and children. In C. Reed (Ed.), The learning of language. Appleton-Century-Crofts.

Bromberg, H., \& Wexler, K. (1995). Null subjects in Wh questions. MIT Working Papers in Linguistics, 26, 221-248.

Chomsky, N. (1981). Lectures on government and binding: The Pisa lectures. Mouton de Gruyter.

Crousaz, I. D., \& Shlonsky, U. (2003). The distribution of a subject clitic pronoun in a Franco-Provençal dialect and the licensing of pro. Linguistic Inquiry, 34(3), 413-442.

Guasti, M. T. (1996). Acquisition of Italian interrogatives. In H. Clahsen (Ed.), Language acquisition and language disorders (Vol. 14, p. 241). John Benjamins Publishing Company.

Guasti, M. T. (2004). Language acquisition: The growth of grammar. MIT Press.

Guasti, M. T., Gavarró, A., de Lange, J., \& Caprin, C. (2008). Article omission across child languages. Language Acquisition, 15(2), 89-119.

Haegeman, L. (2000). Adult null subjects in non pro-drop languages. In M.-A Friedemann and L. Rizzi (Eds.), The acquisition of syntax: studies in comparative developmental linguistics. (pp. 129-169). London: Longman.

Haegeman, L., \& Ihsane, T. (2001). Adult null subjects in the non-pro-drop languages: Two diary dialects. Language Acquisition, 9(4), 329-346.

Holmberg, A. (2005). Is there a little pro? Evidence from Finnish. Linguistic Inquiry, $36(4), 533-564$.

Holmberg, A. (2010a). Null subject parameters. In T. Biberauer, A. Holmberg, I. Roberts, \& M. Sheehan (Eds.), Parametric variation: Null subjects in minimalist theory (pp. 88-124). Cambridge University Press.

Holmberg, A. (2010b). The null generic subject pronoun in Finnish: a case of incorporation in T. In T. Biberauer, A. Holmberg, I. Roberts, \& M. Sheehan (Eds.), Parametric variation: Null subjects in minimalist theory. (pp. 200-230). Cambridge University Press.

Huang, C.-T. J. (1984). On the distribution and reference and empty pronouns. Linguistic Inquiry, 15(4), 531-574.

Hyams, N. (1986). Language acquisition and the theory of parameters. D. Reidel Publishing Company.

Hyams, N. (1991). A reanalysis of null subjects in child language. In J. Weissenborn, H. Goodluck, \& T. Roeper (Eds.), Theoretical issues in language acquisition: Continuity and change in development (pp. 249-267). Lawrence Erlbaum Associates.

Jaeggli, O., \& Safir, K. J. (1989). The null subject parameter and parametric theory. In O. A. Jaeggli \& K. J. Safir (Eds.), The null subject parameter (Vol. 15, pp. 1-44). Springer Netherlands.

Jaggar, P. (2001). Hausa. Amsterdam: Benjamins. 
Kenstowicz, M. (1989). The null subject parameter in modern Arabic dialects. In O. A. Jaeggli \& K. J. Safir (Eds.), The null subject parameter (Vol. 15, pp. 263-275). Springer Netherlands.

Krämer, I. (1993). The licensing of subjects in early child language. MIT Working Papers in Linguistics, 19, 197-212.

Landau, I. (2006). Chain resolution in Hebrew VP-fronting. Syntax 9, 32-65.

Nariyama, S. (2004). Subject ellipsis in English. Journal of Pragmatics, 36(2), 237-264.

Phillips, C. (1995). Syntax at age two: Cross-linguistic differences. Language Acquisition, 17(1-2), 70-120.

Rizzi, L. (1982). Issues in Italian syntax. De Gruyter.

Rizzi, L. (1986). Null objects in Italian and the theory of pro. Linguistic Inquiry, 17, 501-557.

Rizzi, L. (1994). Early null subjects and root null subjects. In T. Hoekstra \& B. D. Schwartz (Eds.), Language acquisition and language disorders (Vol. 8, pp. 151). John Benjamins Publishing Company.

Rizzi, L. (2005). Grammatically-based target inconsistencies in child language. The Proceedings of the Inaugural Conference on Generative Approaches to Language Acquisition - North America, 19-49.

Roberts, I. (2010). A deletion analysis of null subjects. In T. Biberauer, A. Holmberg, I. Roberts, \& M. Sheehan (Eds.), Parametric variation: Null subjects in minimalist theory. Cambridge University Press.

Roeper, T., Rooth, M., Mallis, L., \& Akiyama, A. (1984). The problem of empty categories and bound variables in language acquisition. Unpublished manuscript.

Simões, L. J. (1999). Sujeito nulo na aquisição do Português do Brasil. Cadernos de Estudos Lingüísticos, 36, 105-130.

Slobin, D. (1973). Cognitive prerequisites for the development of grammar. In C. Ferguson \& D. Slobin (Eds.), Studies in child language development. (pp. 175-209). Holt, Rinehart, \& Winston.

Valian, V. (1991). Syntactic subjects in the early speech of American and Italian children. Cognition, 40(1-2), 21-81.

Wang, Q., Lillo-Martin, D., Best, C. T., \& Levitt, A. (1992). Null subject versus null object: Some evidence from the acquisition of Chinese and English. Language Acquisition, 2(3), 221-254.

Wexler, K., \& Manzini, M. R. (1987). Parameters and learnability in binding theory. In Roeper, T., \& Williams, E. (Eds.), Parameter setting (pp. 41-76). Dordrecht: D. Reidel. 